\title{
THE CRITICAL PERIOD BEFORE BANKRUPTCY
}

\section{JOSEF HERBERT FÜRTH'}

CREDITORS in urging reforms of the bankruptcy laws have commonly complained that the debtors do not declare their insolvency in time to save at least some portion of the assets. Strangely enough, the consequences of the debtor's delay have not been analyzed in detail. The bankruptcy cases collected by the Institute of Human Relations at Yale offer, thereiore, an unique opportunity. A sufficient number of cases has been collected for our study, and we know from the articles of the supervisors ${ }^{1}$ the exact basis of the research, what possible errors have to be considered, and in what way the material might be further developed.

The questionnaires used in this investigation did not contain any direct question concerning the length of the period before bankruptcy during which the debtor was insolvent. However, the bankrupt was asked how long before bankruptcy he experienced difficulties in meeting his bills. This question is suficient for our purpose. Difficulties in meeting one's bills are, of course, not always a symptom of insolvency. Delay in making collection and, especially in times of panic, difficulties in securing credit may bring the most solvent business man into temporary straits. But if the financial troubles continue during months or years, the excuse of "frozen assets" cannot be used. The debtor" must not insert an asset in his balance-sheet at a valuation higher than can be realized upon a sale within a reasonable time. If a debtor is unable to procure within a reasonable time the money necessary to meet his obligations, we can state that his assets do not cover his liabilities and that he is insolvent.

\footnotetext{
$* J$. D. University of Vienna, 1921; member of the Austrian Bar; Research Fellow 1931-32; author of various articles in Austrian periodicals.

This article could not have been written without the help and advice of Professor William $O$. Douglas, who placed at my disposal the materials and technical resources of the Institute of Human Relations, Dr. Dorothy S. Thomas, who kindly guided me through the intricacies of statistics, and Mr. Frank P. Keenan, who helped me to master the difficulties of expression in a foreign language.

1 Clark, Douglas and Thomas, The Business Failures Project I (1930) 39 YaLE L. J. 1013; Douglas and Thomas, The Business Failures Project II (1931) 40 YaLe L. J. 1034; Thomas, Sọme Aspects of Socio-legal Rescarel at Yale (1931) 37 AMIER. Journ. of Sociology 213; Douglas, Some Funetional Aspects of Bankriptcy (1932) 41 YALE L. J. 329; Douglas and Marshall, A Factual Study of Bankmptcy Administration and Some Suggestions (1932) 32 COL. L. REv. 25.
} 
The answers to the question-how long before bankruptcy difficulty was experienced in meeting bills, are the bases for our study. The objection may be made that our foundation is uncertain in that the bankrupts might have exaggerated the length of that time in order to give the impression that they have not yielded to the first difficulty. In practice, however, bankrupts are not commonly criticized for going into bankruptcy too soon, and they have therefore no reason to invent excuses for such acts. On the contrary, the bankrupts in many cases minimize the length of time of their difficulties, due in part to the overoptimism of the average debtor. ${ }^{2}$

But this tendency does not make the answers of the debtor's worthless. Probably they do not accurately reflect the length of the term, but they are reliable inasmuch as the true duration of the difficulties is at least not shorter than the time stated. The resulting figures are biased in the same direction, but the amount of uncertainty becomes relatively unimportant when the figures are compared with each other. ${ }^{\mathrm{B}}$

The questionnaires in 501 bankruptcies and 42 friendly adjustments in New Jersey during the fiscal year 1928-29 and 882 bankruptcies and 51 friendly adjustments in Boston during the fiscal year 1930-31 were examined in connection with this article. The New Jersey cases, with very few exceptions, and the Boston friendly adjustments were business failures. The Boston bankruptcy cases included 606 business failures; the remaining 276 bankrupts were wage-earners. Because of the fundamental difference between the economic aspects of business and wageearner failures, we will treat these two classes separately.

The time from the beginning of the difficulties to the filing of the petition in bankruptcy is referred to as the critical period. In the cases of friendly adjustments this period terminates, of course, at the date of the assignment in favor of the creditors.

In table 1 is shown the division of the cases in "time-groups" according to the length of their critical period. It will be noted that the petition was filed within the four months foreseen by some provisions of the Bankruptcy Act ${ }^{4}$ in very few of the

2 NOEL, HISTORY OF BANKRUPTCY (1919) 184.

3 Botrley, Elements of Statistics (1926) 191.

4 Sec. 3, subdiv. b. concerning the time of filing creditors" petitions of bankruptcy; Sec. 14, subdiv. b., clause (4), concerning refusal of dischargo because of fraudulent transfer of property; Seg. 60 , subdivisions $a$. and $b_{\text {, }}$ concerning voidability of preferences; Sec. 67 , subdivisions $c$, $a$, and $f$, concerning nullity of liens, conveyances and judgments; Sec. 68, subdiv, $b_{\text {, }}$ concerning prohibited set-offs. 
cases. In New Jersey, $19 \%$ of the friendly adjustments were entered into and $11.4 \%$ of the bankruptcy petitions were filed within this period. In Boston, the corresponding figures were $6 \%$ of the friendly adjustments, 7.5\% of the business banluruptcies and $1.9 \%$ of the wage-earner bankruptcies. On the other hand, a critical period of two years or more was found in $25 \%$ of the New Jersey friendly adjustments, $30.5 \%$ of the New Jersey bankruptcies, $42 \%$ of the Boston friendly adjustments, $46.9 \%$ of the Boston business bankruptcies and $66.4 \%$ of the Boston wage-earner bankruptcies. The average lengths of the critical periods are distributed as follows:

one year-New Jersey friendly adjustments

one year and a half-New Jersey bankruptcies

one year and a half-Boston friendly adjustments

two years-Boston business bankruptcies

three years and a half-Boston wage-earner bankruptcies

These figures correspond with the median in all classes with the exception of the Boston wage-earner cases where the median amounts to somewhat less than three years.

The reliability of these figures is not constant in the various classes. In the Boston bankruptcies only $0.65 \%$ of the business failures and $5.0 \%$ of the wage-earner cases had a critical period of unknown length. But the length of this period was unknown in $21.4 \%$ of the New Jersey bankruptcies, almost $30 \%$ of the New Jersey friendly adjustments and $62 \%$ of the Eoston friendly adjustments. The "probable error" increases, of course, in the same way, and therefore the figures must be used with some caution.

In tables 2-4 the relation between the duration of the critical period and the amount of the assets is shown. To be sure, the sums scheduled by the bankrupts on which the figures of the questionnaires must rely, are as a rule above the true value of the assets. But here again the error due to the one-sided bias will diminish as we are dealing only with the comparison of the sums.

In the New Jersey bankruptcies the percentage of cases with no assets or assets of no more than $\$ 500$ amounts to $9.7 \%$ of the cases with a critical period of less than four months, against $40.0 \%$ of the cases with a critical period of four years or more. In the Boston bankruptcies we find sufficient cases without any assets to consider them separately. Of the business failures $32.6 \%$ of the cases with a critical period under four months, and $62 \%$ of the cases with a critical period of four years or more, 
have no assets. Among the wage-earners the percentage rises from $58 \%$ in the group with a critical period of less than one year to $83.5 \%$ in the group with a critical period of four years or more.

These figures reveal also important differences between the New Jersey bankruptcies and the Boston business and wageearner cases. In $23.6 \%$ of the New Jersey bankruptcies the assets are not more than $\$ 500$ and in $41.0 \%$ the assets are more than $\$ 5,000$. But $67.8 \%$ of the Boston business bankruptcies have assets of not more than $\$ 500$ and only $10.7 \%$ have assets of more than $\$ 5,000$. Among the Boston wage-earner cnses there are $92.6 \%$ with assets of not more than $\$ 500$ and $3.0 \%$ with assets of more than $\$ 5,000$. On the other hand, the friendly adjustment cases show in New Jersey, $12 \%$ with assets of not more than $\$ 500$ and $22 \%$ with assets of more than $\$ 5,000$, whereas in Boston no cases with assets of not more than $\$ 500$ are found and $51 \%$ have assets of more than $\$ 5,000$. Thus we notice that the Boston cases, which showed average critical periods appreciably longer than those of the New Jersey cases, also exhibit average assets substantially smaller in amount.

Before discussing these figures we must consider the possibility that the differences between the amount of assets within the different groups might be due to a difference in the size of business. If that were true, the amount of liabilities, which is the best index of the size of the business, would be proportionate to the assets. But upon examination no such tendency was discovered in the bankruptcy cases.

Only among the friendly adjustments does the difference in liabilities explain the divergence in assets. In Boston, no cases with liabilities of not more than $\$ 2,500$ can be found, wherens in New Jersey, this group amounts to $27 \%$ of the total. This deviation, obviously due to a different policy of the associntions concerned with assignments in both districts, explains the fact that the Boston friendly adjustments, in contrast to New Jersey, have no cases with assets up to $\$ 500$ although their average critical period is longer.

But as for the bankruptcy cases, not only between the different "time-groups," but also between the total averages of the New Jersey failures and both classes of Boston cases, the differences in the amount of assets are always in clear correlation to the length of the critical period. Therefore we can state as a general proposition: the longer the critical period, the smaller the assets.

\section{IV}

The relation between the length of the critical period and the different types of business was also examined. We consider in 
this connection the New Jersey and Boston business failures only, as there is, of course, no correlation between the insolvency of wage-earners and the type of business in which they are employed.

The most important types of business failures both in New Jersey and Boston, are retailers and contractors (including realestate men), forming in New Jersey 55.8\% and 26.4\%, in Boston $34.6 \%$ and $29.1 \%$, respectively. The percentage of retailers is, in both districts, highest in the group with a critical period under four months, being in New Jersey 75.6\%, in Boston 48.9 $c$. It is smallest in the group with a critical period of four years or more, namely $28.6 \%$ and $22.1 \%$, respectively. On the other hand, the percentage of contractors rises from the first "timegroup" to the groups of cases with a critical period of two years or more, in New Jersey from $8.9 \%$ to $36.9 \%$, in Boston from $15.6 \%$ to $36.8 \%$. In a similar way, the percentage of professional men rises and the percentage of manufacturers declines according to the growth of the critical period.

The objection could be made that the "rule of decreasing assets" as stated above, was only the result of these changes in the composition of the different "time groups" as to the types of business. But an examination of the most distinct type of business, the contractor cases, proves that this is not true. The differences in the amount of assets between these cases and the total are quite irrelevant in the Boston failures, whereas the deviation in the New Jersey cases is counterbalanced by the fact that the "rule of decreasing assets" can be found also in the contractors' class.

The economic importance of a business depends not only upon its character but also, within each group, upon the amount of capital needed. A study was made of the relation between the length of the critical period and the capitalization at the beginning of the business. In the New Jersey bankruptcies a businesscapital of not more than $\$ 500$ was found in $9.7 \%$ of the cases with a critical period of less than four months, and in 22.7? the cases with a critical period of four years or more. In the Boston business bankruptcies the percentage rose from $22.2 \%$ in the first "time-group" to $38.1 \%$ in the group with a critical period of four years or more. On the other hand, in New Jersey $46.3 \%$ of the cases with a critical period under four months, and only $22.7 \%$ of the cases with a critical period of four years or more, had started business with a capital of more than $\$ 5,000$. In Boston, the corresponding figures were $35.6,0$ and $14.5 \%$, respectively.

At first glance this seems strange; but a high amount of 
capitalization always indicates the need of large capital and not always the sufficiency of the provided sum. Wherever high capital is needed at the initiation of the business, the need for credit will be correspondingly large during its development. The insolvency, cutting off new credits, will in such a case soon lead to bankruptcy. ${ }^{5}$

The length of the critical period is also affected by non-economic influences such as nationality and tradition. The nationality of the bankrupts was inquired into at the New Jersey investigntion, but later the question was dropped. Instead, in Boston the bankrupts were asked about the place of birth of their fathers and themselves. We may use the place of birth as a substitute for nationality, considering a person an American if both he and his father were born in the United States, and as an alien if he or his father were born in the foreign country.

The bulk of the Boston bankrupts consisted of Americans, Russians and Poles, Englishmen and Canadians. Almost 50\%. of the wage-earners were American. Among the business-mon, the Russians and Poles led with $27.9 \%$, leaving the American second with $23 \%$. In general, the nationality groups do not show any specific correlation with the length of the critical period. With one exception: both among wage-earners and business mon, but especially among the latter, the Russians and Poles show a tendency to shorter critical periods than the other races. Among the business bankrupts with a critical period under four months 42.2\% were Russians and Poles. Among the cases with a critical period of four years or more, the percentage was only $24.7 \%$. The corresponding figures in the wage-earner class were $18 \%$ and $11 \%$, respectively.

The business tradition is shown by the length of time the bankrupt had spent in the trade in which he failed. ${ }^{\circ}$ The bankrupts who spent less than two years in the business in which they failed, constitute $55.0 \%$ of the cases with a critical period under four months in New Jersey and $48.9 \%$ in Boston. The percentages of bankrupts who were two or three years in their business reach the highest points, in the groups with a critical period of from four months to less than one year and of from one year to less than two years, $28.0 \%$ and $18.5 \%$ in Now Jersoy and $30.4 \%$ and $29.6 \%$ in Boston, respectively. The business men with from four to five years experience in their trade aro

5 In this connection it may be noted that in New Jersey as woll as in Boston corporations had a somewhat shorter critical period than individuals. 6 This does not apply, of course, to wage-earners. 
most numerous in the groups with a critical period of from two to less than three and from three to less than four years, amounting in these groups to $23.0 \%$ and $18.5 \%$ in New Jersey and to $18.8 \%$ and $22.7 \%$ in Boston, respectively. Finally, the bankrupts who spent six years or more in their business, reach by far the highest percentage in the group with a critical period of four years or more, namely $78.6 \%$ in New Jersey and $59.7 \%$ in Boston.

The figures clearly indicate that the average length of the critical period is proportionate to the average length of time spent by the bankirupt in the business in which he failed. This tendency checks the operation of the "rule of decreasing assets." A very inefficient business man will dissipate more assets in a short critical period than the average banlaupt. On the other hand, a longer critical period will not be quite so disastrous to a bankrupt with many years of experience in his business as to a newcomer: That the "rule of decreasing assets" nevertheless prevails, indicates the strength of the destructive influence of the critical period.

The effects of the critical period on the bankrupts estate must determine the attitude of the law. The dissipation of most of the assets occurs, as shown by the "rule of decreasing assets," during the critical period. The law must, therefore, first try to shorten the critical period, and secondly give means to annul acts committed during this period to the damage of the creditors.

To shorten the critical period means to compel the debtor to declare his insolvency as soon as it occurs, not to force him into bankruptcy. On the contrary, friendly adjustments are probably in many cases better for both creditor and debtor:" But the debtor must give his creditors the opportunity to decide what to do in full knowledge of his real situation. The quantity of cases without assets in the Boston bankruptcies demonstrates the consequences of a system where the typical answer to the question; "What adjustments were attempted after" the difficulties began?" consists in a simple "none."

The crudest attempt to shorten the critical period may be made by means of penal provisions. But courts and juries are not likely to punish bankrupts for mere negligence, notwithstanding the letter of the law. The denial of discharge would be a better weapon against debtors who as soon as they are insolvent neither submit to their creditors an offer of adjustment nor file a peti-

7 Billig, What Price Bankiruptcy (1929) 14 ConNenl LAW QUarTersy 413; Douglas and Miarshall, op. cit. supra note 1 , at 45 .

8 Douglas and Marshall, op. cit. supra note 1 , at 42. 
tion in bankruptcy.9 Such a provision would induce the debtors to declare their insolvency at least before their tardiness becomes so apparent that the most benevolent judge cannot overlook it. Besides, it would relieve the courts of the great bulk of cases in which the debtor seeks a discharge with no assets left to pay one cent to his creditors.

On the other side, the debtor who declares his insolvency in time should be rewarded by granting him a judicial composition without formal bankruptcy proceeding. Under the Bankruptcy Act, ${ }^{20}$ a debtor can obtain a composition only if he pays at once considerable sums. But a bankrupt has, as a rule, no ready money at his disposal. Therefore, a reasonable time should be allowed for the payment of the consideration.11

Another way to shorten the critical period consists in facilitating the filing of creditors' petitions in bankruptcy. The Bankruptcy Act ${ }^{2}$ renders these petitions very difficult by asking the creditor to prove some "acts of bankruptcy." Besides, there is no reason to limit the provable "acts of bankruptcy" within four months before the filing of the petition as the average critical period in which those acts occur is much longer.13

The second end of the law, annulment of acts committed during the critical period, cannot be treated in this article, as it involves the controversy between the protection of the "secur"ity of trade" and the "equal rights of creditors." But insofar as we are willing to favor the "equal rights of creditors," it is not reasonable to restrict the voidability of acts to the period of four months before the filing of the petition. Most acts by which the creditors are damaged are committed in the beginning of the insolvency, and the creditors are protected only if the time to set those acts aside is not less than the average critical period.

${ }^{9}$ The English law provides for denial or suspension of the dischargo if "the bankrupt has continued to trade after knowing himself to be insolvent." But there is no reason to favour the debtor who is so negligent that ho does not even know his situation, or the debtor who does not continue to trado but simply lives on his creditors' money.

${ }^{10}$ Sec. 12, subdiv. b.

11 Most European statutes provide that the composition shall not bo confirmed if the consideration does not amount to a certain proportion of tho liabilities. But if the creditors prefer a small dividend to nothing, thoro is no reason to deprive them of that. Besides, these provisions have proved to be ineffective as, in many cases, the creditors conclude, and the courts confirm, compositions, knowing that only a part of the promised consideration will be paid. Fürth, Zwangsvollstrecleung und Insolvenzverfathon (Esecution of Judgments and Insolvency Proceedings) (1930) 48 ZENTRALBLATT FǗR DIE JURISTISCHE PRAXIS 338.

12 Sec. 3, subdiv. b.

${ }^{13}$ It will be noted that the Report of the Judicial Conference of Senior Circuit Judges, 1931, comes, from a very different point of view, in many points to the same practical conclusions. 8 AMr. BANKRUPTCY REviEW 75 . 


\section{VII}

Related as it is to the fluctuations of the business cycle, bankruptcy is, in the first place, a problem of economics. Unfortunately, however, the economists have not, until recently, dealt with the problem to the same extent as the lawyers. ${ }^{13}$

To be sure, one thing has always been known: bankruptcies are less frequent in times of prosperity than in times of depression. ${ }^{15}$ But even this truth becomes questionable if we think of the length of the critical period. Bad times, of course, mean difficulties for business, but we have seen that difficulties mean bankruptcy only after a critical period of one year or more, on the average. The curve of bankruptcies should, therefore, show a lag of one year or more behind the curve of depression. However, such a lag is generally not to be found..13

Trying to solve this paradox, we must once more consider the difference in the length of the critical period in the New Jersey and the Boston cases. It is easy to understand that friendly adjustments show a shorter critical period than bankruptcies and that wage-earners are able to delay banlaruptcy longer than business men. But the distinct difference between the New Jersey and the Boston business bankruptcies needs explanation. The differences in the amount of liabilities, not very lar'ge themselves, have been found to have no influence as to the length of the critical period. Divergences in the types of business and the average time spent by the bankrupts in their trades do not exist in a relevant quantity; the same is probably true as to the racial composition. To be sure, the New Jersey cases include failures from rural districts, too, whereas the Boston bankruptcies were limited to an urban area. But in New Jersey the influence of the metropolitan district of New York prevails; besides, it is not very probable that the critical period is shorter in rural than in urban areas. On the contrary, people in small towns and villages are, as a rule, for social reasons, more afraid of bankruptcy than business men in large cities.

There is only one great difference between the New Jersey and the Boston bankruptcies; the first occurred during the season of 1928-29 when the depression had not yet arrived; the

\footnotetext{
14 Holm-Nielsen has announced a book on "Banluruptey Law and Economics," which may fill the gap.

15 Pietri Torrelli, Dei Fallimenti come Indic dello Stato Economico e delle Sue Variazioni (Bankruptcies as Index of the Economic Situation and Their Variations) (1931) 12 RrvisTA BANCARIA 107, points out different meanings of the increase and decrease in bankruptcies.

16 Compare, for instance, charts 8 and 21, in Mrtcheld, Business Cycles (1930).
} 
second, two years later when the economic crisis was in full bloom.

The general economic situation deeply affects the psychology of the insolvent debtor. In times of prosperity he thinks that "something" will change and make an end to his difficulties, and the creditors are apt to share his optimism. When depression comes, not only is his business hit harder than a sounder firm, but he also despairs of ending his struggle in victory. He sees other firms, better founded and highly esteemed, driven into difficulties, and bankruptcy becoming a common event instead of a contemptible crime. So, at last, the debtor decides to do what the state of his affairs required long before. He becomes $\Omega$ bankrupt not purely as an economic but, at least partly, as a psychological victim of depression.

As long as this psychological influence is greater than the material squeeze of depression, more firms with old difficulties will go bankrupt than debtors who were solvent until the beginning of the crisis. Therefore, not only the absolute quantity of bankruptcies will increase as soon as the depression is to be felt, but also the percentage of cases with a long critical period will rise over its normal standard. In the course of time, the bulk of the firms with old difficulties will be wiped out, and the increase of bankruptcies reduced to the purely economic victims of the crisis. The percentage of cases with a long critical period will begin to decline and, finally, fall below the level of times of prosperity. When depression passes its maximum, the deficit of "old" cases will soon become greater than the increment of "young" ones; the quantity of bankruptcies as a whole will fall. At the end of the depression, also, the number of "young" bankruptcies will decline, till in times of prosperity the normal relation between cases with long and short critical periods is reached again.

This hypothesis could explain both the difference between the average length of the critical period in different stages of depression, and the coincidence of the curves of bankruptcy and depression in spite of the existence of the critical period. Un. fortunately, the material on which it is based is too limited and too uncertain for safe scientific statements. But it would be worth while to make further research in this direction, comparing the critical period during the different stages of depression within territories of sufficient extent and including the principal types of business. For if the hypothesis proves to be correct, the changes in the length of the critical period might be used for the determination of the actual stage of the business. cycle and the forecasting of economic developments. 
TABLE I-NEW JeRsey aND BostoN FaILURes

Nomber and Fercentages of failures with a critical rariel of

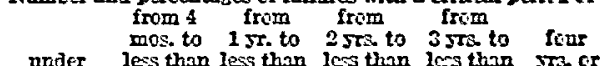

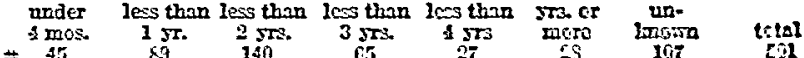

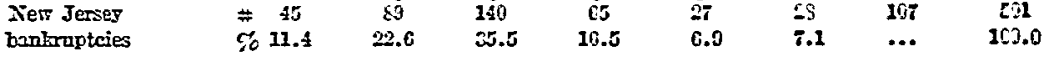

$\begin{array}{llllllllll}\text { Boston business } & \# & 45 & 115 & 160 & 152 & 53 & 7 & 4 & 03\end{array}$

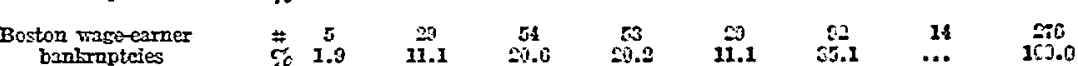

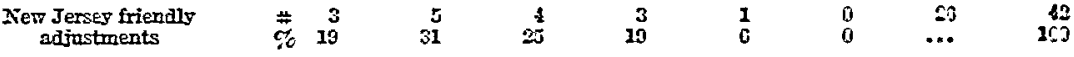

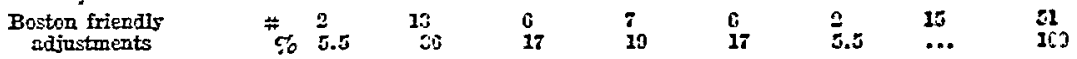

\section{Table II-NEW Jersex Famures}

Nomber and

Dereentage of

Barkraptcies with a critieal roricd of

$$
\text { from from from from }
$$

4 mos. to 1 sr. to $25 \pi$ to $35 \pi$ to four

fallures

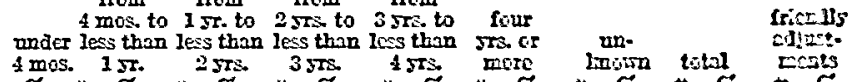

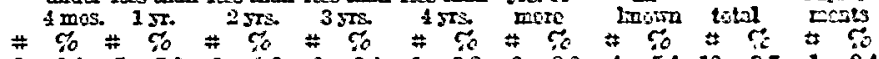

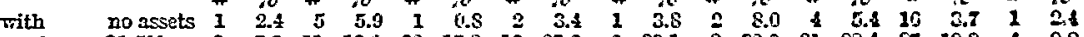
$\begin{array}{llllllllllllllllllll}\text { assets } & 51-509 & 3 & 7.3 & 11 & 13.0 & 22 & 17.2 & 10 & 27.6 & 0 & 23.1 & 8 & 30.0 & 21 & 28.4 & 87 & 10.9 & 4 & 0.5\end{array}$

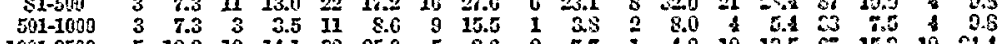

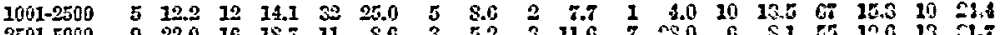
$\begin{array}{lllllllllllllllllll}2501-5000 & 9 & 22.0 & 16 & 18.7 & 11 & 8.6 & 3 & 5.2 & 3 & 11.6 & 7 & -9.9 & 6 & \$ .1 & 55 & 12.0 & 13 & 0.7\end{array}$

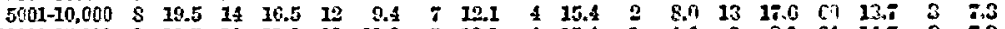
$\begin{array}{lllllllllllllllllll}10001-25.000 & 8 & 19.5 & 10 & 11.8 & 2 S & 21.8 & 7 & 12.1 & 4 & 15.4 & 1 & 4.0 & 6 & 8.1 & C & 14.5 & 5 & i * 3\end{array}$

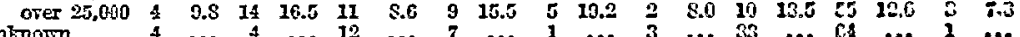

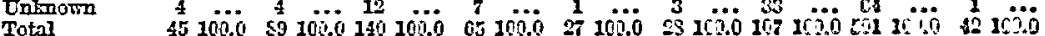

\section{Table III-Boston Business Failures}

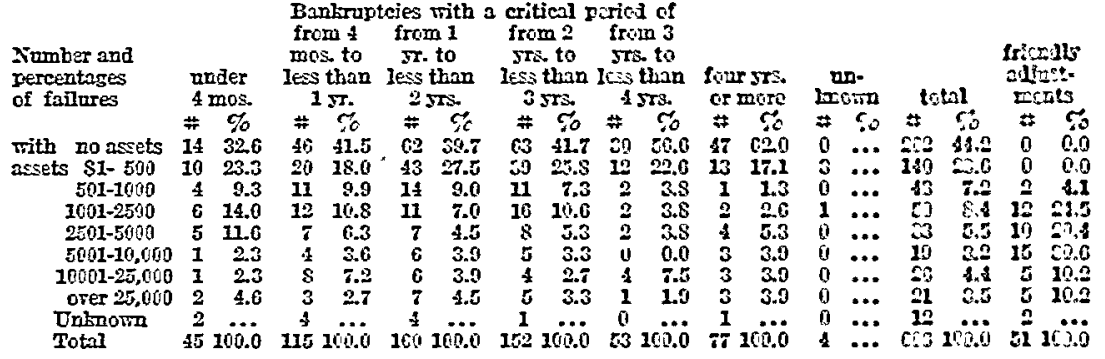

\section{TABLE IV-Boston Wage-earner BaNkruftcies}

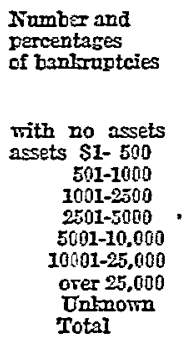

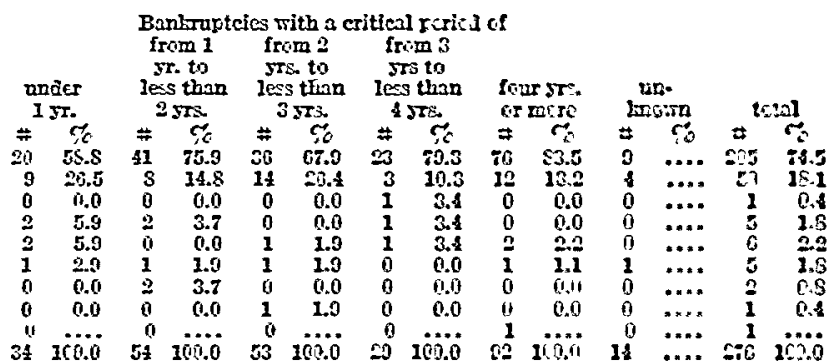

Note. The tables to sections IV and V were not printed because of limitations of space. 